\title{
Efektivitas Penggunaan Metode Pembelajaran Demonstrasi di SMK Negeri 4 Pangkep
}

\author{
Ayu Purwandira, Risma Niswaty, Muhammad Darwis \\ Pendidikan Administrasi Perkantoran, Universitas Negeri Makassar \\ Email: risma.niswaty@unm.ac.id
}

\begin{abstract}
Penelitian ini bertujuan untuk mengetahui tingkat keefektifan penggunaan metode demonstrasi pada kelas X mata pelajaran kearsipan di sekeloh tersebut. Penelitian ini menggunakan jenis pendekatan kualitatif. Informan dalam penelitian ini sebanyak 5 (lima) orang. Pengumpulan data dilakukan melalui tekhnik observasi, wawancara dan dokumentasi. Hasil penelitian ini menunjukkan bahwa guru mata pelajaran kearsipan di SMK Negeri 4 Pangkep dalam menerapkan metode demonstrasi telah melakukan tahap persiapan dengan cukup baik. Selain tahap persiapan adapun tahap pelaksanaan yang terdiri dari langkah pembukaan dan langkah pelaksanaan. Pada langkah pembukaan guru masih melewatkan beberapa kegiatan yang cukup mempengaruhi jalannya proses demonstrasi, oleh sebab itu pada langkah pembukaan dikatakan masih belum cukup baik. Namun hal tersebut berbading terbalik dengan langkah pelaksanaan yang telah dilakukan dengan baik, kegiatan-kegiatan pada langkah ini dilakukan secara optimal. Pada tahap akhir yaitu tahap mengakhiri, pemberian tugas dan juga evaluasi juga dilakukan dengan cukup baik. Sehingga dari hasil penilaian secara keseluruhan dimulai dari tahap pembukaan, kemudian tahap pelaksanaan dan terakhir pada tahap mengakhiri metode demonstrasi pada mata pelajaran kearsipan kelas X di SMK Negeri 4 Pangkep telah berjalan dengan cukup efektif.
\end{abstract}

Kata kunci: Efektivitas, Metode Pembelajaran, Pembelajaran Demonstrasi

\begin{abstract}
This study aims to determine the effectiveness of the use of demonstration methods in class X archival subjects around it. This study uses a qualitative approach. The informants in this study were 5 (five) people. Data collection is done through observation, interview and documentation techniques. The results of this study indicate that archival subject teachers in State Vocational High School 4 Pangkep in implementing the demonstration method have carried out the preparation stage quite well. In addition to the preparation stage, the implementation phase consists of opening steps and implementation steps. In the opening step the teacher still missed some activities that were enough to influence the course of the demonstration process, therefore the opening step was said to be still not good enough. But this is reversed with the implementation steps that have been done well, the activities in this step are carried out optimally. In the final stage, the end stage, assignment and evaluation are also carried out quite well. So that from the overall assessment results starting from the opening stage, then the implementation phase and finally at the end stage of the demonstration method in the archival subjects of class X at Pangkep State Vocational High School 4 has run quite effectively.
\end{abstract}

Keywords: Effectiveness, Learning Methods, Demonstration Learning 
20| Jurnal Office, Vol. 4, No. 1, Januari-Juni 2018

\section{PENDAHULUAN}

Pendidikan merupakan suatu proses pembelajaran yang dilakukan oleh seseorang untuk memperoleh pengetahuan ataupun keterampilan yang biasanya dilakukan melalui proses pengajaran maupun pelatihan(Jamaluddin, Salam, Yunus, \& Akib, 2017; Salam, 2015). Pembelajaran bukan hanya dapat dilakukan melalui pengajaran maupun pelatihan, tetapi dari lingkungan tempat tinggal juga dapat diambil pembelajaran, melalui perilaku sosial masyarakat, nilai-nilai dan norma-norma, adat istiadat masyarakat, dan dari kegiatan bersosialisasi dengan masyarakat yang ada di lingkungan tempat tinggal untuk membentuk karakter peserta didik yang sesuai dengan norma dan nilai yang baik yang terdapat pada kehidupan bermasyarakat(Awaru, 2017; Lestyarini, 2012; Saggaf, 2016; Sukmawati, 2017).

Pendidikan mempunyai peran yang sangat penting dalam pembangunan nasional dan menjadikan masyarakat yang lebih berkualitas dalam hal pemikiran, tingkah laku, sikap, pengendalian diri, dsb. Di dalam UU No.20 tahun 2003 tentang Sistem Pendidikan Nasional menyatakan bahwa, Pendidikan adalah adalah usaha sadar dan terencana untuk mewujudkan suasana belajar dan proses pembelajaran agar siswa secara efektif mengembangkan potensi dirinya untuk memiliki kekuatan spiritual keagamaan, pengendalian diri, kepribadian, kecerdasan, akhlak mulia serta keterampilan yang diperlukan dirinya,masyarakat, bangsa dan negara.

Dalam proses pembelajaran yang berperan penting di dalamnya adalah pendidik dan peserta didik itu sendiri. Akan tetapi, pendidik memegang peran yang lebih besar dan lebih berpengaruh terhadap pembentukan karakter peserta didik. Pendidik bukan hanya sekedar mengajar, akan tetapi pendidik juga diharapkan dapat membimbing, mengarahkan, melatih dan menilai peseta didik, untuk mewujudkan itu semua, pendidik diharuskan untuk memiliki pengetahuan yang lebih dan menguasai berbagai kemampuan, mulai dari cara pendekatan terhadap peserta didik, strategi pembelajaran, model pembelajaran, sampai medote yang digunakan seorang pendidik dalam menyampaikan tujuan dari suatu pembelajaran.

Metode merupakan suatu cara atau upaya yang dilakukan oleh pendidik dalam proses pembelajaran untuk mencapai tujuan dari pembelajaran itu (Salam, Zunaira, \& Niswaty, 2016). Metode pembelajaran yang baik ialah metode yang dapat menyesuaikan dengan materi pembelajaran yang akan diajarkan dan juga kemampuan peserta didik. Sebab jika tidak sesuai akan berdampak kurang baik pada proses pembelajaran, dan peserta didik bisa saja sulit untuk memahami pelajaran yang di sampaikan oleh pendidik. Pendidik dalam menerapkan metode pembelajaran juga seharusnya melihat situasi dan kondisi peserta didik. Mempertimbangkan segala sesuatu yang berhubungan dan akan mempengaruhi proses pembelajran yang sedang berlangsung, sehingga tujuan dari pembelajaran pun tidak tercapai sesuai dengan apa yang diharapkan. Salah satu metode yang biasa diterapkan oleh pendidik dalam mengajar adalah metode demontrasi merupakan cara penyampaian pelajaran oleh pendidik dengan cara memperagakan langsung inti dari materi pelajaran yang diajarkan kepada peserta didik. 
Ayu Purwandira, Risma Niswaty, Muhammad Darwis; Efektivitas Penggunaan Metode Pembelajaran... $\mid 21$

\section{METODE}

Penelitian ini merupakan penelitian kualitatif yaitu peneliti yang menggambarkan secara naratif dengan berdasarkan pada data-data hasil penelitian yang ditelaah secara objektif dari hasil wawancara, observasi dan dokumentasi. Adapun data-data yang dapat diperoleh dari hasil penelitian, agar dapat menjawab segala permasalahan menyangkut penelitian, yaitu: 1) Data Primer, 2) data sekunder. Data primer merupakan data yang diperoleh dari hasil wawancara yang berisi pertanyaan yang berkaitan dengan keefektifan penggunaan metode pembelajaran demonstrasi pada mata pelajaran kearsipan yang diperoleh dari informan penelitian, yaitu: a) Wakasek Kurikulum SMK Negeri 4 Pangkep (1 orang), b) Guru Mata Pelajaran Kearsipan (1 orang), c) Siswa kelas X Jurusan Administrasi Perkantoran (3 orang). Sedangkan data sekunder merupakan data pendukung hasil penelitian yang diperoleh dari hasil observasi dan dokumentasi, hasil dokumentasi berupa struktur organisasi sekolah, visi-misi sekolah, dan dokumen-dokumen lain yang berkaitan dengan data sekolah.

\section{HASIL PENELITIAN DAN PEMBAHASAN}

Berdasarkan hasil penelitian yang dilakukan Peneliti mengenai efektivitas penggunaan metode pembelajaran demonstrasi pada mata pelajaran kearsipan kelas X di SMK Negeri 4 Pangkep, secara umum dapat dikatakan telah berjalan secara efektif. Hal tersebut dapat dilihat dari beberapa data yang didapatkan melalui penelitian yang dilakukan melalui tahap observasi, dan data yang diberikan oleh beberapa informan dari hasil wawancara serta dokumentasi yang didapatkan oleh Peneliti. Penjelasan setiap informan mengenai proses pembelajaran yang dilakukan oleh guru mata pelajaran kearsipan yang menerapkan metode demonstrasi yang di dalamnya terdapat beberapa tahap, mulai dari tahap persiapan, tahap pelaksanaan dan tahap mengakhiri, telah dilaksanakan dengan baik oleh guru tersebut.

\section{Tahap Persiapan}

Pada tahap persiapan merupakan tahap perencanaan. Memperkirakan gambaran mengenai apa yang akan dilakukan serta tindakan apa yang akan diambil di dalam pembelajaran di dalam kelas. Pada tahap persiapan ada beberapa langkah yang sepatutnya dilaksanakan, agar pembelajaran di dalam kelas berjalan sesuai dengan yang telah direncanakan. Pada umumnya, guru mata pelajaran kearsipan telah melakukan persiapan pembelajaran menggunakan metode demonstrasi dengan cukup efektif.

Guru yang bersangkutan telah menentukan tujuan pembelajaran di dalam RPP yang dibuat, yang nantinya hendak dicapai oleh peserta didik di dalam kelas setalah mengikuti proses pembelajaran. Perumusan tujuan ini akan membantu guru untuk dapat mengetahui apa saja yang harus Ia lakukan di dalam kelas pada saat proses pembelajaran sedang berlangsung. Selain itu, guru mata pelajaran kearsipan juga telah membuat garis besar langkah-langkah demonstrasi yang akan dilakukan di dalam kelas. Garis besar langkah demonstrasi ini, dibuat dalam bentuk draf.

Setelah merumuskan tujuan dari pembelajaran, membuat garis besar langkah-langkah demonstrasi, selanjutnya yang dilakukan pada tahap persiapan yaitu melakukan uji coba 
demonstrasi sebelum di lakukan di dalam kelas, akan tetapi guru mata pelajaran kearsipan tidak melakukan kegiatan. Hal tersebut tidaklah cukup mempengaruhi jalannya proses demonstrasi, sebab guru tersebut juga telah membuat catatan berupa garis besar langkah demonstrasi. Sehingga apabila dilihat secara umum, dapat disimpulkan tahap persiapan yang telah dilakukan oleh guru mata pelajaran kearsipan menggunakan metode pembelajaran demonstrasi dapat dinilai sudah cukup efektif.

\section{Tahap Pelaksanaan}

Pada tahap pelaksanaan terbagi menjadi dua langkah yaitu langkah pembukaan dan langkah pelaksanaan.

Langkah Pembukaan. Langkah pembukaan cukup berperan dalam keberhasilan proses pembelajaran. Dalam langkah ini, guru terlebih dahulu mengatur tempat duduk peserta didik, guru selanjutnya seharunya mengemukakan tujuan pembelajaran kepada peserta didik, Saat guru melakukan demonstrasi, pastinya ada hal yang mesti dilakukan oleh peserta didik, peserta didik tidak boleh dibiarkan hanya diam, itu untuk mencegah agar mereka tidak melamun dalam proses pembelajaran. Setelah mengemukakan tujuan yang harus dicapai oleh peserta didik, guru juga semestinya memberikan arahan atau tugas kepada peserta didik mengenai kegiatan apa yang mesti dilakukan pada saat guru sedang mendemonstrasikan materi pelajaran.

Langkah Pelaksanaan. Pada langkah pelaksanaan ini juga terdapat beberapa kegiatan yang mesti dilakukan untuk membuat proses demonstrasi berjalan dengan lancar dan mencapai tujuan yang telah dirumuskan sebelumnya. Kegiatan awal pada langkah pelaksanaan terlebih dahulu yaitu menarik perhatian peserta didik dengan cara melakukan suatu kegiatan yang dapat memusatkan perhatian peserta didik agar memperhatikan proses demonstrasi. Pada saat melakukan demonstrasi ciptakanlah suasana yang menyenangkan agar peserta didik lebih mudah dalam memahami proses demonstrasi. Pada saat pembelajaran demonstrasi, guru seharunya memerhatikan reaksi peserta didik pada saat proses demonstrasi sedang berlangsung. Guru tidak boleh hanya fokus pada materi pelajaran yang didemonstrasikan, namun guru juga harus sering melihat dan memperhatikan gerak-gerik peserta didik. Dalam mendemonstrasikan materi pelajaran, guru juga harus memberikan kesempatan peserta didik untuk berpikir atau mengajukan pertanyaan mengenai materi demonstrasi, entah itu pada saat proses demonstrasi sedang berlangsung atau pada saat demonstrasi telah berakhir. Ini dilakukan agar peserta didik tidak terkendala dalam menyelesaikan tugas yang akan diberikan setelah demosntrasi selesai dilakukan.

Berdasarkan data yang telah diperoleh dari hasil observasi peneliti dan jawaban dari informan melalui wawancara, dapat disimpulkan bahwa pada tahap pelaksanaan yang dilakukan oleh guru kearsipan menggunakan metode demonstrasi telah dilaksanakan dengan cukup efektif. Hal ini dikarenakan dari beberapa kegiatan yang ada pada langkah pembukaan dan langkah pelaksanaan telah dilakukan dengan cukup baik. Walaupun dalam langkah pembukaan tidak dilakukannya pengaturan tempat duduk peserta didik, ini dikarenakan pada saat belajar kearsipan peserta didik belajar pada ruang laboratorium perkantoran yang tempat duduk didalamnya telah diatur sedemikian rupa agar seluru peserta didik dapat melihat guru pada saat mengajar. 
Selain tidak mengatur tempat duduk peserta didik, guru juga tidak memberikan tugas kepada peserta didik pada saat proses demonstrasi sedang berlangsung. Guru hanya memberikan arahan kepada peserta didik untuk memperhatikan jalannya proses demonstrasi. Jika dipikirkan secara mendalam, hal ini dapat dinilai cukup benar. Sebab tidak semua peserta didik dapat memiliki kemampuan yang sama. Tidak semua peserta didik dapat memperhatikan guru mengajar sambil mencatat hal-hal yang penting atau hal-hal yang lain. Hanya sebagian kecil peserta didik yang dapat melakukan dua kegiatan secara bersamaan.

\section{Tahap Mengakhiri}

Pada pelaksanaan metode demonstrasi, tahap mengakhiri dilakukan dengan cara melakukan beberapa kegiatan yang akan merangsang peserta didik untuk mengasah pikiran mereka, seperti dilakukannya pemberian tugas yang berhubungan dengan materi pelajaran yang telah didemonstrasikan oleh guru. Selain pemberian tugas yang bertujuan untuk merangsang peserta didik berpikir secara mandiri dan bekerja secara mandiri pula, guru juga hendaknya melakukan evaluasi bersama dengan peserta didik setelah tugas yang diberikan telah selesai dikerjakan ini bertujuan untuk menilai sejauh mana tingkat keberhasilan dari tujuan pembelajaran. Evaluasi yang dimaksud adalah evaluasi mengenai proses demonstrasi yang telah dilakukan oleh guru.

Berdasarkan data yang diperoleh dari hasil penelitian yang dilakukan oleh peneliti, dapat ditarik kesimpulan bahwa tahap mengakhiri pada penggunaan metode demonstrasi yang diterapkan oleh guru mata pelajaran kearsipan dapat dikatakan sudah cukup efektif. Dikatakan demikian sebab, kegiatan yang terdapat pada tahap mengakhiri metode pembelajaran demonstrasi telah dilakukan dengan benar oleh guru mata pelajaran kearsipan.

\section{SIMPULAN}

Berdasarkan hasil penelitian yang telah dilakukan oleh Peneliti dimulai dari tahap observasi selanjutnya tahap wawancara kemudian dokumentasi, maka dapat disimpulkan bahwa dalam upaya guru dalam menerapkan dan menggunakan metode pembelajaran demonstrasi pada mata pelajaran kearsipan kelas X di SMK Negeri 4 Pangkep sudah berjalan cukup efektif. Dikatakan cukup efektif sebab jika dilihat dari ketiga indikator dalam penelitian ini yaitu tahap persiapan, tahap pelaksanaan dan tahap mengakhiri, setiap indikator dinilai sudah cukup efektif dalam pelaksanaannya. Kegiatan-kegiatan yang terdapat pada setiap tahap, dilakukan dengan benar, sehingga itulah setiap tahap disimpulkan sudah cukup efektif. Meskipun dalam pelaksanaannya masih ada beberapa kegiatan yang tidak dilakukan oleh guru mata pelajaran kearsipan seperti, uji coba demonstrasi pada tahap pelaksanaan, pengaturan tempat duduk dan pemberian tugas kepada peserta didik pada saat proses demonstrasi sedang berlangsung yang terdapat pada langkah pembukaan pada tahap pelaksanaan, serta evaluasi yang berlainan maksud pada tahap mengakhiri. Hal tersebut tidak memengaruhi proses demonstrasi, sehingga metode demonstrasi yang diterapkan tetap berjalan secara efektif. 
24| Jurnal Office, Vol. 4, No. 1, Januari-Juni 2018

\section{DAFTAR PUSTAKA}

Awaru, A. O. T. (2017). Membangun Karakter Bangsa Melalui Pendidikan Berbasis Multikultural Di Sekolah. In Prosiding Seminar Nasional Himpunan Sarjana Ilmu-ilmu Sosial (Vol. 2, hal. 221-230).

Jamaluddin, J., Salam, R., Yunus, H., \& Akib, H. (2017). Pengaruh Budaya Organisasi terhadap Kinerja Pegawai pada Dinas Pendidikan Provinsi Sulawesi Selatan. Jurnal Ad'ministrare, $4(1), 25-34$.

Lestyarini, B. (2012). Penumbuhan semangat kebangsaan untuk memperkuat karakter Indonesia melalui pembelajaran bahasa. Jurnal pendidikan karakter, (3).

Saggaf, H. M. S. (2016). Kebijakan Pendidikan Di Era Otonomi Daerah Dalam Memperkuat Karakter Bangsa. Jurnal Ilmiah Ilmu Administrasi Publik, 5(2), 106-112.

Salam, R. (2015). Penerapan Fungsi Administrasi Perkantoran Modern berbasis Daya Saing Organisasi dalam menyongsong MEA 2015. In SEMINAR NASIONAL "Revolusi Mental dan Kemandirian Bangsa Melalui Pendidikan Ilmu-Ilmu Sosial dalam Menghadapi MEA 2015 " Himpunan Sarjana Pendidikan Ilmu-Ilmu Sosial Indonesia (Vol. 1, hal. 186-190).

Salam, R., Zunaira, Z., \& Niswaty, R. (2016). Meningkatkan Hasil Belajar Membuat Dokumen melalui Penggunaan Model Pembelajaran Kooperatif Tipe Make a Match (Mencari Pasangan). Jurnal Office, 2(2), 173-180.

Sukmawati, S. (2017). Implementasi Pendidikan Karakter di Sekolah Menengah Pertama Negeri Kabupaten Maros. Jurnal Ad'ministrare, 4(2), 76-82. 